\title{
Acute onset supraclavicular lymphadenopathy coinciding with intramuscular mRNA vaccination against COVID-19 may be related to vaccine injection technique, Spain, January and February 2021
}

María Fernández-Prada, ${ }^{1,2}$, Irene Rivero-Calle ${ }^{2,3,4}$, Ana Calvache-González ${ }^{5}$, Federico Martinón-Torres ${ }^{2,3,4}$

1. Vaccines Unit, Preventive Medicine and Public Health Department, Vital Álvarez-Buylla Hospital, Health Care Service of Asturias, Mieres, Spain

2. WHO Collaborating Centre for Vaccine Safety, Santiago de Compostela, Spain

3. Translational Pediatrics and Infectious Diseases, Hospital Clínico Universitario and Universidad de Santiago de Compostela (USC), Santiago de Compostela, Spain

4. Genetics, Vaccines and Pediatric Infectious Diseases Research Group (GENVIP), Instituto de Investigación Sanitaria de Santiago and Universidad de Santiago de Compostela (USC), Santiago de Compostela, Spain

5. Digestive Surgery Service, Hospital Clínico Universitario de Santiago de Compostela, Santiago de Compostela, Spain

Correspondence: Federico Martinón-Torres (federico.martinon.torres@sergas.es)

Citation style for this article:

Fernández-Prada María, Rivero-Calle Irene, Calvache-González Ana, Martinón-Torres Federico. Acute onset supraclavicular lymphadenopathy coinciding with intramuscular mRNA vaccination against COVID-19 may be related to vaccine injection technique, Spain, January and February 2021 . Euro Surveill. 2021;26(10): pii=2100193. https://doi.org/10.2807/1560-7917.ES.2021.26.10.2100193

Monitoring adverse reactions following immunisation is essential, particularly for new vaccines such as those against COVID-19. We describe 20 cases of acute onset of a single supraclavicular lymphadenopathy manifesting between $24 \mathrm{~h}$ and 9 days after ipsilateral intramuscular administration of an mRNA-based COVID-19 vaccine, referred to our WHO Collaborating Centre for Vaccine Safety. Our results indicate that the swelling of supraclavicular lymph nodes following immunisation may constitute a benign and self-limited condition, related to a higher than recommended injection site.

The monitoring of adverse reactions associated with vaccination is one of the most important factors in vaccine safety. Although vaccines are among the safest drugs currently on the market, vaccines are not completely risk-free, and adverse events may occur following vaccination. Careful assessment of any adverse events following immunisation is essential to distinguish those that are causally linked to the vaccination from those just coincident in time, in order to prevent vaccine distrust or misperceptions [1]. The objective of this rapid communication was to report a series of adverse reactions consisting of acute onset supraclavicular lymphadenopathy coinciding with vaccination against coronavirus disease (COVID-19).

\section{Case series}

Here we describe a series of 20 clinical cases referred to our World Health Organization (WHO) Collaborating Centre for Vaccine Safety, reporting the acute onset of a single supraclavicular lymphadenopathy coinciding with the ipsilateral intramuscular administration of a dose of an mRNA vaccine (Figure). All patients were female healthcare workers and had received between 15 January and 22 February 2021, an ipsilateral intramuscular administration of an mRNA-based vaccine against COVID-19 (Comirnaty, Pfizer-BioNTech (Puurs, Belgium) in 19 cases or mRNA-1273, Moderna (Madrid, Spain) in one case), with different administration days and vaccine lot numbers.

All 20 cases were women, with ages ranging from 25 to 60 (median: 44) years (Table). None had a history of severe or unusual adverse reactions following immunisation. Two of the cases had a prior history of thyroid disease (follicular adenoma and thyroid cancer), a third case was diagnosed with autoimmune thyroiditis in the course of the diagnostic work-up, and another two cases had Sjögren syndrome (one associated with hypertension and the other with systemic lupus erythematosus). In five patients, fine needle puncture aspiration was performed with results showing reactive inflammatory signs, with lymphocytic infiltrate and active germinal centres. In one patient, a mammography was also performed, with no pathological finding. All lymphadenopathies had inflammatory symptoms (pain, swelling), were rounded and mobile, and all but one appeared in the first $24 \mathrm{~h}$ to 9 days after vaccine administration. The remaining patient detected the adenopathy 24 days after vaccination, prompted by contact with another affected case, but she retrospectively recognised minor local symptoms in the preceding days.

In six cases, the symptoms occurred after the first vaccine dose, while the remaining 14 happened after the 
Supraclavicular lymphadenopathy ipsilateral to the vaccination arm (left), COVID-19 vaccination, Spain, 2021

A.

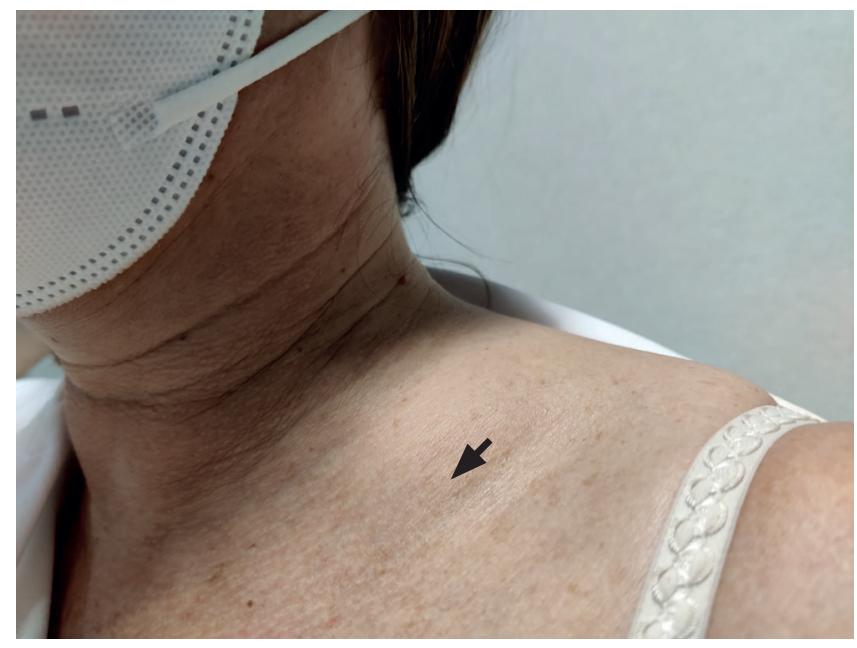

B.

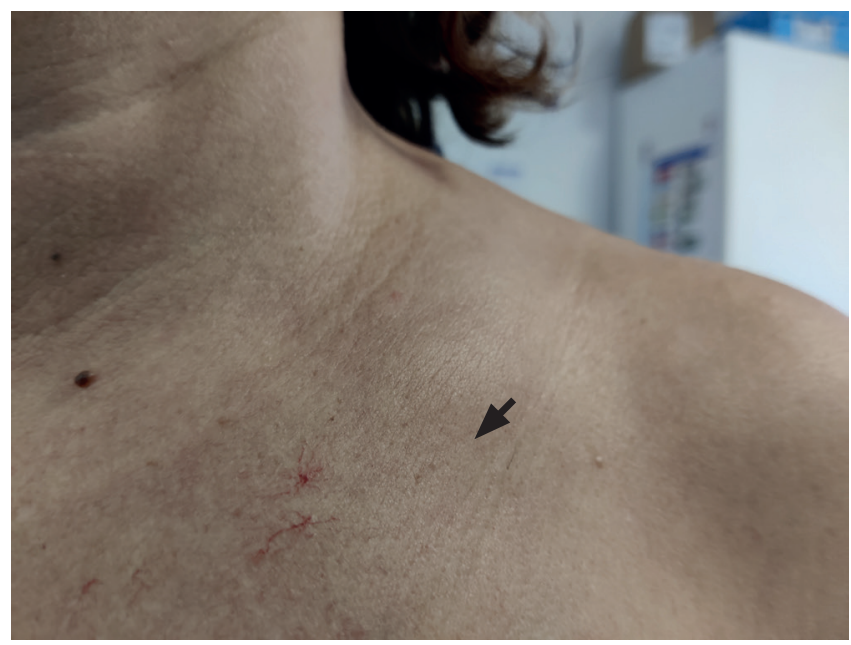

A. The lymphadenopathy appeared 1 day after the first vaccine dose, and it is in resolution, with significant reduction in size since onset.

B. The lymphadenopathy appeared 7 days after the second vaccine dose and it is in resolution.

second dose. All of them completed the two-dose vaccination schedule. Twelve of the 20 patients spontaneously reported that the intramuscular injection point was unusually high, and nearly all (17/20) acknowledged a similar perception when they were asked about this specifically (either compared with the previous dose administration or in relation to their theoretical expectation about the exact location of the point of injection).

In three cases, infraclavicular lymphadenopathies with the same characteristics were also present. There were no signs of excess inflammation in the deltoid region. None of the cases had fever $\left(38^{\circ} \mathrm{C}\right)$. Splenomegaly was also absent. The rest of their physical examination was unremarkable. Cases are being followed up: all of them have improved clinically, and 15 completely resolved between 5 and 16 days since onset.

\section{Ethical statement}

Informed consent from the patients was obtained before the clinical data collection. The patients agreed with the publication of the reported results.

\section{Discussion}

Regional lymphadenopathies may constitute a sign of medical concern [2]. Although the most frequent cause is infection, neoplastic origin is also possible, particularly in certain locations such as the supraclavicular fossa [2]. Axillary lymphadenopathies after vaccination have been described for live attenuated vaccines such as Bacillus Calmette-Guérin [3], measles-mumps-rubella [4] or varicella [5] but also, more exceptionally, for inactivated vaccines. Axillary swelling or tenderness due to ipsilateral lymphadenopathy in the vaccination arm has recently been reported as an uncommon adverse reaction after the Pfizer-BioNTech vaccine (affecting up to one in 100 people) [6] and as very common after the Moderna vaccine (up to one in 10 people) [7]. However, supraclavicular lymphadenopathy had not previously been described as related to any of these vaccines.

An enlarged lymph node in the supraclavicular location is a concerning finding which may suggest either primary lymphatic malignancy, infection in the mediastinum or a metastatic malignancy from the abdomen, prompting complementary examinations $[8,9]$. Supraclavicular lymph nodes drain the neck but mainly they drain structures in the thorax and abdomen. A regional lymphadenopathy may develop in lymph nodes that drain the vaccination site. This phenomenon has been reported to appear in the first 2 weeks after vaccination and is related to local activation of the immune response. Less frequently, the location reported is supraclavicular, which has been described as associated with vaccination with influenza $A\left(\mathrm{H}_{1} \mathrm{~N}_{1}\right)$ [10] or human papillomavirus (HPV-9) vaccines [11].

Our cases developed supraclavicular adenopathy ipsilateral to the site of vaccination against COVID-19 without other signs or symptoms of interest. Although four cases had pre-existing conditions that might impact on their immune system, no specific relationship has been previously described between their underlying diseases and any specific adverse reactions to vaccination. Our hypothesis is that the immunisation technique may be related to the location of the adenopathy, with the supraclavicular territory and not the axillary being the most frequent drainage area in the event 
Characteristics of healthcare workers with supraclavicular lymphadenopathy after COVID-19 vaccination, Spain, 2021 $(\mathrm{n}=20$, all female $)$

\begin{tabular}{|c|c|c|c|c|c|c|c|c|c|c|}
\hline Number & $\begin{array}{l}\text { Age } \\
\text { group } \\
\text { (years) }\end{array}$ & & Clinical history & $\begin{array}{l}\text { COVID-19 } \\
\text { history } \\
\text { (date of } \\
\text { diagnosis) }\end{array}$ & $\begin{array}{l}\text { ARNm vaccine } \\
\text { name (vaccine } \\
\text { lot number) }\end{array}$ & Dose & $\begin{array}{l}\text { Side of } \\
\text { injection }\end{array}$ & $\begin{array}{c}\text { Onset } \\
\text { date of } \\
\text { symptoms } \\
\text { (days since } \\
\text { vaccination) }\end{array}$ & $\begin{array}{l}\text { Duration of } \\
\text { symptoms } \\
\text { (outcome) }\end{array}$ & $\begin{array}{c}\text { Medical } \\
\text { examinations }\end{array}$ \\
\hline 1 & $30-35$ & & No & No & $\begin{array}{c}\text { Pfizer-BioNTech } \\
\text { (E)6134) }\end{array}$ & 2nd & Left & $\begin{array}{l}28 \operatorname{Jan} 21 \\
(1 \text { day }) \\
\end{array}$ & $\begin{array}{l}5 \text { days } \\
\text { (resolved) }\end{array}$ & None \\
\hline 2 & $30-35$ & & No & No & $\begin{array}{c}\text { Pfizer-BioNTech } \\
\text { (E)6134) }\end{array}$ & 2nd & Left & $\begin{array}{l}30 \text { Jan } 21 \\
\text { (1 day) }\end{array}$ & $\begin{array}{l}10 \text { days } \\
\text { (resolved) }\end{array}$ & None \\
\hline 3 & $25-30$ & & No & No & $\begin{array}{c}\text { Pfizer-BioNTech } \\
\text { (EK9788) }\end{array}$ & $1 \mathrm{st}$ & Left & $\begin{array}{l}21 \text { Jan } 21 \\
\text { (2 days) }\end{array}$ & $\begin{array}{l}7 \text { days } \\
\text { (resolved) }\end{array}$ & Yes $^{\mathrm{a}}$ \\
\hline 4 & $30-35$ & & No & $\begin{array}{l}\text { Yes } \\
(5 \mathrm{Nov} \\
2020)\end{array}$ & $\begin{array}{l}\text { Pfizer-BioNTech } \\
\text { (EK9788) }\end{array}$ & $1 \mathrm{st}$ & Left & $\begin{array}{l}1 \text { Feb } 21 \\
\text { (1 day) }\end{array}$ & $\begin{array}{l}6 \text { days } \\
\text { (resolved) }\end{array}$ & None \\
\hline 5 & $45-50$ & & No & No & $\begin{array}{c}\text { Pfizer-BioNTech } \\
(\text { EL8723) }\end{array}$ & 2nd & Left & $\begin{array}{l}4 \text { Feb } 21 \\
\text { (1 day) }\end{array}$ & $\begin{array}{l}9 \text { days } \\
\text { (in resolution) }\end{array}$ & None \\
\hline 6 & $45-50$ & & No & No & $\begin{array}{c}\text { Pfizer-BioNTech } \\
\text { (EK9788) }\end{array}$ & 2nd & Left & $\begin{array}{l}31 \text { Jan } 21 \\
\text { (o days) }\end{array}$ & $\begin{array}{l}15 \text { days } \\
\text { (in resolution) }\end{array}$ & None \\
\hline 7 & $25-30$ & & No & No & $\begin{array}{c}\text { Pfizer-BioNTech } \\
(\text { EL8723) }\end{array}$ & 2nd & Left & $\begin{array}{l}8 \text { Feb } 21 \\
\text { (3 days) }\end{array}$ & $\begin{array}{l}5 \text { days } \\
\text { (resolved) }\end{array}$ & None \\
\hline 8 & $55-60$ & & No & No & $\begin{array}{l}\text { Pfizer-BioNTech } \\
\text { (EK9788) }\end{array}$ & 2nd & Left & $\begin{array}{l}5 \text { Feb } 21 \\
\text { (1 day) }\end{array}$ & $\begin{array}{l}\text { (15 days) } \\
\text { (resolved) }\end{array}$ & None \\
\hline 9 & $55-60$ & & No & No & $\begin{array}{c}\text { Pfizer-BioNTech } \\
\text { (EK9788) }\end{array}$ & 2nd & Left & $\begin{array}{l}9 \text { Feb } 21 \\
\text { (7 days) }\end{array}$ & $\begin{array}{l}30 \text { days } \\
\text { (in resolution) }\end{array}$ & None \\
\hline 10 & $55-60$ & Yes & $\begin{array}{l}\text { Sjögren syndrome, } \\
\text { arterial hypertension }\end{array}$ & No & $\begin{array}{c}\text { Pfizer-BioNTech } \\
\text { (EK9788) }\end{array}$ & $1 \mathrm{st}$ & Left & $\begin{array}{l}10 \text { Feb } 21 \\
\text { (9 days) }\end{array}$ & $\begin{array}{l}10 \text { days } \\
\text { (resolved) }\end{array}$ & None \\
\hline 11 & $35-40$ & Yes & $\begin{array}{c}\text { Thyroid follicular } \\
\text { adenoma }\end{array}$ & No & $\begin{array}{l}\text { Pfizer-BioNTech } \\
\text { (EMo477) }\end{array}$ & 2nd & Left & $\begin{array}{l}5 \text { Feb } 21 \\
\text { (3 days) }\end{array}$ & $\begin{array}{l}9 \text { days } \\
\text { (resolved) }\end{array}$ & Yes $^{a}$ \\
\hline 12 & $40-45$ & & No & $\begin{array}{l}\text { Yes } \\
(20 \text { Jan } \\
2021)\end{array}$ & $\begin{array}{l}\text { Pfizer-BioNTech } \\
\text { (EK9788) }\end{array}$ & 2nd & Left & $\begin{array}{l}10 \text { Feb } 21 \\
(1 \text { day })\end{array}$ & $\begin{array}{l}8 \text { days } \\
\text { (resolved) }\end{array}$ & None \\
\hline 13 & $45-50$ & Yes & Autoimmune thyroiditis & No & $\begin{array}{c}\text { Pfizer-BioNTech } \\
\text { (EMo477) }\end{array}$ & $1 s t$ & Left & $\begin{array}{l}21 \text { Jan } 21 \\
(6 \text { days })\end{array}$ & $\begin{array}{l}24 \text { days } \\
\text { (in resolution) }\end{array}$ & Yes $^{a}$ \\
\hline 14 & $50-55$ & & No & No & $\begin{array}{l}\text { Pfizer-BioNTech } \\
\text { (EK9788) }\end{array}$ & $1 \mathrm{st}$ & Left & $\begin{array}{l}30 \text { Jan } 2021 \\
\text { (1 day) }\end{array}$ & $\begin{array}{l}7 \text { days } \\
\text { (resolved) }\end{array}$ & None \\
\hline 15 & $35-40$ & & No & No & $\begin{array}{l}\text { Pfizer-BioNTech } \\
\text { (EK9788) }\end{array}$ & 2nd & Left & $\begin{array}{c}22 \text { Jan } 2021 \\
\text { (1 day) }\end{array}$ & $\begin{array}{l}16 \text { days } \\
\text { (resolved) }\end{array}$ & Yes $^{b}$ \\
\hline 16 & $55-60$ & Yes & $\begin{array}{c}\text { Systemic lupus } \\
\text { erythematosus, Sjögren } \\
\text { syndrome }\end{array}$ & No & $\begin{array}{c}\text { Pfizer-BioNTech } \\
\text { (EL8723) }\end{array}$ & 2nd & Left & $\begin{array}{l}7 \text { Feb } 2021 \\
\text { (2 days) }\end{array}$ & $\begin{array}{l}10 \text { days } \\
\text { (resolved) }\end{array}$ & None \\
\hline 17 & $50-55$ & & No & No & $\begin{array}{c}\text { Pfizer-BioNTech } \\
\text { (EM6950) }\end{array}$ & 2nd & Left & $\begin{array}{c}18 \text { Feb } 2021 \\
\text { (1 day) }\end{array}$ & $\begin{array}{l}5 \text { days } \\
\text { (resolved) }\end{array}$ & None \\
\hline 18 & $45-50$ & Yes & $\begin{array}{c}\text { Asthma and thyroid } \\
\text { cancer }\end{array}$ & No & $\begin{array}{c}\text { Pfizer-BioNTech } \\
\text { (EP9598) }\end{array}$ & 2nd & Left & $\begin{array}{c}24 \text { Feb } 2021 \\
\text { (2 days) }\end{array}$ & $\begin{array}{l}7 \text { days } \\
\text { (in resolution) } \\
\end{array}$ & None \\
\hline 19 & $35-40$ & & No & No & $\begin{array}{l}\text { Pfizer-BioNTech } \\
\text { (EK9788) }\end{array}$ & 2nd & Left & $\begin{array}{c}26 \text { Feb } 2021 \\
\text { (24 days) } \\
\end{array}$ & $\begin{array}{l}30 \text { days } \\
\text { (in resolution) }\end{array}$ & None \\
\hline 20 & $35-40$ & & No & No & $\begin{array}{c}\text { Moderna } \\
(300042460)\end{array}$ & $1 \mathrm{st}$ & Right & $\begin{array}{c}22 \text { Jan } 2021 \\
\text { (4 days) }\end{array}$ & $\begin{array}{l}32 \text { days } \\
\text { (in resolution) }\end{array}$ & Yes $^{\mathrm{a}}$ \\
\hline
\end{tabular}

a Ultrasonography and fine-needle aspiration puncture.

${ }^{b}$ Ultrasonography, mammography, and fine-needle aspiration puncture. 
that the injection is administered at a higher location than recommended. The deltoid muscle is considered the optimal injection site for vaccines in the arm, concretely in the middle of the deltoid muscle, about two to three finger-widths below the acromion process. A range of injuries such as shoulder pain and dysfunction have been related to vaccination performed too high on the arm, where several anatomical structures exist, including the posterior circumflex humeral artery, the anterior branch of the axillary nerve or the subacromial-subdeltoid bursa [12]. All our patients where healthcare workers and most of them reported an unusually high point of puncture, not respecting the recommended distance between the acromion and the middle of the deltoid muscle. Nineteen of 20 cases were vaccinated in the left arm. This may simply be related to the fact that in right-handed people, vaccination is usually applied in the opposite arm, although it should be noted that left supraclavicular lymph nodes have more extensive drainage sites and drain more distant regions than nodes on the right side [8].

Our series may be just anecdotal. However, the recognition of supraclavicular lymphadenopathy as a self-limited inflammatory reaction in the context of ipsilateral arm vaccination may guide patients' differential diagnosis and avoid unnecessary complementary examinations (blood analysis, locoregional echography, fine needle puncture aspiration, etc). Furthermore, if our hypothesis is true, the onset of this adverse reaction would be easily preventable with adequate training of vaccinators on the technique of administrating intramuscular vaccines. Taking into account the mass vaccinations taking place in Europe in spring, this information may be particularly relevant, not only to perform further surveillance of this event but also to prevent it through adequate vaccination technique and to consider this possibility in the differential diagnosis of an acute onset supraclavicular lymphadenopathy.

Our results cannot state specific incidence as these patients were not systematically referred to our centre and came from three different regions across Spain. The majority (90\%) of mRNA vaccine doses distributed in Spain were Pfizer-BioNTech. We do not think that our findings have an impact on the safety profile of mRNA COVID-19 vaccines. Although the acute events following immunisation described in this series are timerelated with vaccination, we cannot establish a causal relationship. However, our findings may call for further vigilance and the consideration of clinicians when evaluating acute supraclavicular lymphadenopathy after COVID-19 vaccination. According to our results, this constitutes a benign and self-limited condition related to injection-site technique.

\section{Acknowledgements}

We would like to acknowledge the cooperation from $M^{\mathrm{a}}$ Ruth Lobeto Martínez (Occupational Risk Prevention Service, Vital Álvarez-Buylla Hospital, Health Care Service of Asturias,
Spain). Also thanks to all the participants for their willingness to collaborate.

\section{Conflict of interest}

FM-T has received honoraria from GSK group of companies, Pfizer Inc, Sanofi Pasteur, MSD, Seqirus, Biofabri and Janssen for taking part in advisory boards and expert meetings and for acting as a speaker in congresses outside the scope of the submitted work. FM-T has also acted as principal investigator in randomised controlled trials of the abovementioned companies as well as Ablynx, Gilead, Regeneron, Roche, Abbott, Novavax, and Medlmmune, with honoraria paid to his institution. FM-T receives support for research activities from the Instituto de Salud Carlos III (Proyecto de Investigación en Salud, Acción Estratégica en Salud): Fondo de Investigación Sanitaria (FIS; Plo70069/Pl1000540/ $\mathrm{Pl} 1601569 / \mathrm{Pl}$ 1901090) del plan nacional de I+D +I and 'fondos FEDER'. IRC reports personal fees from GSK, Pfizer, Sanofi Pasteur and MSD for taking part in advisory boards and expert meetings; and honoraria paid to her institution as sub-investigator in RCTs for GSK, Pfizer, Sanofi Pasteur, MSD, Sequirus, Janssen, Ablynx, Regeneron, Roche, Abbott, Novavax and MedImmune outside the submitted work.

\section{Authors' contributions}

FMT, MFP, IRC and ACG collected all the cases and related information. FMT and MFP wrote the first draft. FMT, MFP, IRC and ACG participated in the development and the review of the manuscript and approved the final submitted version.

\section{References}

1. World Health Organization Regional Office for Europe (WHO /Europe). Vaccine safety and false contraindications to vaccination. Copenhagen: WHO/Europe; 2017. Available from: https://www.euro.who.int/_data/assets/pdf_ file/ooog/351927/WHO-Vaccine-Manual.pdf

2. Riva G, Sensini M, Peradotto F, Scolfaro C, Di Rosa G, Tavormina P. Pediatric neck masses: how clinical and radiological features can drive diagnosis. Eur J Pediatr. 2019;178(4):463-71. https://doi.org/10.1007/s00431-018-33059 PMID: 30643937

3. Al-Hammadi S, Alkuwaiti NS, Ghatasheh GA, Al Dhanhani H, Shendi HM, Elomami AS, et al. Adverse events of the BCG (Bacillus Calmette-Guérin) and rotavirus vaccines in a young infant with inborn error of immunity. Case Reports Immunol. 2020;2020:8857152. https://doi.org/10.1155/2020/8857152 PMID: 33354374

4. Marin M, Fiebelkorn AP, Bi D, Coleman LA, Routh J, Curns AT, et al. Adverse events among young adults following a third dose of measles-mumps-rubella vaccine. Clin Infect Dis. 2020:ciaa1090. https://doi.org/10.1093/cid/ciaa1090 PMID: 32766827

5. Diaz-Mitoma F, Halperin SA, Scheifele D. Reactogenicity to a live attenuated varicella vaccine in Canadian children. Can J Infect Dis. 2000;11(2):97-101. https://doi. org/10.1155/2000/647245 PMID: 18159273

6. European Agency for the Evaluation of Medicinal Products (EMEA). Summary of product characteristics - Comirnaty. Amsterdam: EMEA. [Accessed: 15 Feb 2021]. Available from: https://www.ema. europa.eu/en/documents/product-information/ comirnaty-epar-product-information_en.pdf

7. European Agency for the Evaluation of Medicinal Products (EMEA). Summary of product characteristics - COVID 19 vaccine Moderna. Amsterdam: EMEA. [Accessed: 15 Feb 2021]. Available from: https://www. ema.europa.eu/en/documents/product-information/ covid-19-vaccine-moderna-epar-product-information_en.pdf

8. Banjar FK, Wilson AM. Anatomy, head and neck, supraclavicular lymph node. [Updated 2020 Jul 27]. In: StatPearls [Internet]. Treasure Island (FL): StatPearls Publishing; 2020 Jan-. Available from: https://www.ncbi.nlm. nih.gov/books/NBK544300/ 
9. Cybulska P, Hayes SA, Spirtos A, Rafizadeh MJ, Filippova OT, Leitao M, et al. Prognostic significance of supraclavicular lymphadenopathy in patients with high-grade serous ovarian cancer. Int J Gynecol Cancer. 2019;29(9):1377-80. https://doi. org/10.1136/ijgc-2019-000829 PMID: 31575614

10. Toy H, Karasoy D, Keser M. Lymphadenitis caused by $\mathrm{H}_{1} \mathrm{~N}_{1}$ vaccination: case report. Vaccine. 2010;28(10):2158 6o. https://doi.org/10.1016/j.vaccine.2009.12.043 PMID: 20060084

11. Pereira MP, Flores $P$, Neto AS. Neck and supraclavicular lymphadenopathy secondary to 9-valent human papillomavirus vaccination. BMJ Case Rep. 2019;12(11):e231582. https://doi. org/10.1136/bcr-2019-231582 PMID: 31694828

12. Behrens RH, Patel V. Avoiding shoulder injury from

intramuscular vaccines. Lancet. 2021;397(10273):471. https:// doi.org/10.1016/S0140-6736(21)00192-6 PMID: 33549186

\section{License, supplementary material and copyright}

This is an open-access article distributed under the terms of the Creative Commons Attribution (CC BY 4.0) Licence. You may share and adapt the material, but must give appropriate credit to the source, provide a link to the licence and indicate if changes were made.

Any supplementary material referenced in the article can be found in the online version.

This article is copyright of the authors or their affiliated institutions, 2021. 